\title{
Pemanfaatan Media Virtual Reality Berbasis Kearifan Lokal Melalui Alat Musik SAMPE Untuk Meningkatkan Kemampuan Berpikir Kritis
}

\author{
${ }^{1}$ Lia Angraeni, ${ }^{2}$ Henny Puspitasari, ${ }^{3}$ Eti Sukadi \\ ${ }^{1,3}$ Prodi Pendidikan Fisika IKIP PGRI Pontianak, J1. Ampera No. 99 Pontianak, Kalimantan \\ Barat, 78115 \\ ${ }^{2}$ Prodi Pendidikan TIK IKIP PGRI Pontianak, Jl. Ampera No. 99 Pontianak, Kalimantan \\ Barat, 78115 \\ Email Korespondensi: $\underline{\text { lia060787@gmail.com }}$
}

\begin{tabular}{|c|c|}
\hline Info & bstract \\
\hline $\begin{array}{l}\text { Article History } \\
\text { Received: } 21 \text { April } 2021 \\
\text { Revised: } 28 \text { April } 2021 \\
\text { Published: } 30 \text { June } 2021\end{array}$ & \multirow{2}{*}{$\begin{array}{l}\text { The demand for implementing industrial revolution education } 4.0 \text { is the use of } \\
\text { information technology in the learning process. Virtual Reality (VR) media in } \\
\text { learning is one of the uses of technology in its implementation. Utilization of } \\
\text { VR media must also be accompanied by including the role of local wisdom by } \\
\text { using musical instruments sampe. It is hoped that through learning using VR } \\
\text { media based on local wisdom it can improve students' critical thinking skills. } \\
\text { This study aims to improve critical thinking skills and instill the value of local } \\
\text { wisdom in students. The method used in this research is an experimental } \\
\text { method with the form of pre-experimental research design and one-group } \\
\text { pretest-posttest design research design. Samples were selected using } \\
\text { probability sampling techniques. The research sample was the second semester } \\
\text { students of the Physics Education Study Program of IKIP PGRI Pontianak. The } \\
\text { instrument used was a critical thinking skills test and a questionnaire. This } \\
\text { study obtained qualitative and quantitative data, where quantitative data were } \\
\text { analyzed using statistical analysis t test to see the increase in students' critical } \\
\text { thinking skills. Based on the analysis of the results of the critical thinking test, } \\
\text { it was concluded that there was an increase in students' critical thinking skills } \\
\text { using VR media based on local wisdom, this is because VR media provides } \\
\text { students with direct experience in seeing the concept of vibrations and sound } \\
\text { waves through } 3 D \text { animated visualization of musical instruments until. }\end{array}$} \\
\hline $\begin{array}{l}\text { Keywords } \\
\text { Virtual reality media, local } \\
\text { wisdom, SAMPE Musical } \\
\text { instruments; critical } \\
\text { thinking }\end{array}$ & \\
\hline siArtikel & bstrak \\
\hline $\begin{array}{l}\text { SejarahArtikel } \\
\text { Diterima: } 21 \text { April } 2021 \\
\text { Direvisi: } 28 \text { April } 2021 \\
\text { Dipublikasi:30 Juni } 2021\end{array}$ & \multirow{2}{*}{$\begin{array}{l}\text { Tuntutan pelaksanaan pendidikan revolusi industri } 4.0 \text { adalah pemanfaatan } \\
\text { teknologi informasi dalam proses pembelajaran. Media Virtual Reality (VR) } \\
\text { dalam pembelajaran merupakan salah satu pemanfaatan teknologi dalam } \\
\text { pelaksanaannya. Pemanfaatan media VR juga harus dibarengi dengan } \\
\text { memasukan peran kearifan lokal dengan menggunakan alat musik sampe. } \\
\text { Diharapkan melalui pembelajaran menggunakan media VR berbasis kearifan } \\
\text { lokal dapat meningkatkan kemampuan berpikir kritis mahasiswa. Penelitian ini } \\
\text { bertujuan untuk meningkatkan kemampuan berpikir kritis dan menanamkan } \\
\text { nilai kearifan lokal mahasiswa. Metode yang digunakan dalam penelitian ini } \\
\text { adalah metode eksperimen dengan bentuk penelitian Pre-experimental } \\
\text { designdan rancangan penelitian One-Group Pretest-Posttest Design. Sampel } \\
\text { dipilih dengan menggunakan teknikprobability sampling. Sampel penelitian } \\
\text { adalah mahasiswa Prodi Pendidikan Fisika IKIP PGRI Pontianak semester II. } \\
\text { Instrumen yang digunakan tes keterampilan berpikir kritis. Penelitian ini } \\
\text { diperoleh data kualitatif dan kuantitatif, dimana data kuantitatif dianalisis } \\
\text { menggunakan analisis statistik uji t untuk melihat peningkatan kemampuan } \\
\text { berpikir kritis mahasiswa. Berdasarkan analisis hasil tes berpikir kritis } \\
\text { diperoleh kesimpulan yaitu terdapat peningkatan kemampuan berpikir kritis } \\
\text { mahasiswa menggunakan media VR berbasis kearifan lokal, hal ini disebabkan }\end{array}$} \\
\hline $\begin{array}{l}\text { Kata kunci } \\
\text { Media Virtual } R \\
\text { Kearifan Lokal, } \\
\text { Musik SAMPE, } \\
\text { Kritis }\end{array}$ & \\
\hline
\end{tabular}


karena media VR memberikan mahasiswa pengalaman langsung dalam melihat konsep dari getaran dan gelombang suara melalui visualisasi animasi 3D dari alat musik sampe.

Sitasi: Angraeni, L., Puspitasari, H., \& Sukadi, E. (2021). Pemanfaatan Media Virtual Reality Berbasis Kearifan Lokal Melalui Alat Musik SAMPE Untuk Meningkatkan Kemampuan Berpikir Kritis. Kappa Journal, 5(1), 40-48.

\section{PENDAHULUAN}

Perkembangan pembelajaran abad 21 di Era Revolusi 4.0 ditandai dengan pemanfaatan teknologi informasi dan komunikasi dalam segala segi kehidupan. Dalam bidang pendidikan abad 21, para dosen dituntut untuk dapat melakukan proses pembelajaran dengan menggunakan teknologi digital, sarana informasi dan komunikasi dalam bentuk jaringan internet yang tepat dan sesuai untuk mengakses, melaksanakan dan mengevaluasi serta menghasilkan informasi yang berfungsi dalam proses pembelajaran. Hal ini sesuai dengan isi tentang standar proses pendidikan. Salah satu standar isi menyatakan bahwa pemanfaatan teknologi informasi dan komunikasi dapat meningkatkan efisiensi dan efektivitas pembelajaran. Proses pembelajaran yang biasanya dilakukan dalam perkuliahan di Prodi Pendidikan Fisika IKIP PGRI Pontianak adalah perkuliahan mimbar (lecturing) yang hanya menggunakan teks, alat praktikum, dan gambar saja. Padahal kompetensi lulusan yang diharapkan selain mampu mengusai konsep juga mampu menghasilkan serta memanfaatkan teknologi. Untuk mencapai kompetensi yang diharapkan dalam pembelajaran di perguruan tinggi, banyak media yang bisa digunakan. Salah satunya adalah virtual reality yang mana merupakan extansi dari teknologi komputer multimedia.

Virtual Reality sebuah perangkat teknologi yang menggunakan komputer dan teknologi elektronik untuk menghasilkan suasana realistis tiga dimensi sehingga penggunadapat merasakan melalui penglihatan, pendengaran,sentuhan dan untuk membentuk dunia virtual. Teknologi virtual reality adalah sejenis teknologi antar muka antara manusia dan mesin yang dapat secara nyata mensimulasikan orang-orang seperti berada di lingkungan alami termasuk dengan penglihatan, pendengaran, gerakan dan aksi lain. Tidak hanya dapat dengan jelas menggambarkan lingkungan secara nyata, tetapi virtual reality juga memungkinkan pengguna untuk mengamati lingkungan virtual dan merasa seperti berada ditempat tersebut (Sunarni, dkk, 2014).

Virtual reality atau realitas maya merupakan simulasi suatu lingkungan oleh komputer dengan menciptakan pengalaman nyata kedalam dunia virtual. Teknologi virtual reality itu sendiri bias dirancang untukberbagaitujuan dalam menyelesaikan permasalahan. Menurut Zhang L \& Zheng G (2011) lingkungan digital imersif adalah sebuah interaksi buatan, adegan atau lingkungan yang diciptakan komputer atau sebuah dunia dimana pengguna dapat membenamkan diri kedalam dunia ciptaan tersebut. Penelitian Sulistyowati dan Andy Rachman (2017) yang berjudul Persepsi Efektivitas Pengajaran Bermedia Virtual Reality dalam jurnal semantik 2014 menghasilkan penelitian yang menunjukkan penggunaan media virtual reality dalam pengajaran sangat mendukung untuk materi yang syarat terhadap visualisasi, praktik dan keterbatasan sumber daya. Keinginan dari responden cenderung sangat tinggi $(53,8 \%)$ terhadap penggunaan media virtual reality dalam pembelajaran. Saran yang diberikan untuk penelitian lebih lanjut yaitu perlu adanya mekanisme yang spesifik untuk mendesain virtual reality dengan topik tertentu dan bagaimana implementasinya (efektivitas media virtual reality). Acuan yang digunakan dalam penelitian ini adalah sebagai tinjauan peneliti dalam melaksanakan penelitian karena media virtual reality dapat juga digunakan dalam pengajaran materi getaran dan bunyi dengan berbasis alat sampe', konsep getaran dan bunyi dalam lebih mudah dipahami dalam petikan senar alat musik sampe' dengan memvisualisasikannya secara nyata, sehingga dapat melatih kemampuan 
berpikir kritis mahasiswa. Perbedaannya adalah kalau jurnal membahas perpsepsi efektivitas media virtual reality, sedangkan penelitian ini akan membahas pemanfaatan media virtual reality untuk melatih kemampuan berpikir kritis mahasiswa.

Penelitian Sulistyowati dan Andy Rachman (2017) menunjukkan pemerintahan Indonesia sendiri saat ini sedang menggalakkan digitalisasi materi sekolah (pembelajaran) yakni salah satunya melalui Buku Seri Elektronik dari Kementrian Pendidikan dan Kebudayaan untuk anak Sekolah Dasar, Sekolah Menengah Pertama dan Sekolah Menengah Atas serta Kejuruan. Di Indonesia, Sekolah Dasar hampir tidak ada yang memanfaatkan teknologi virtual reality pada proses pembelajarannya dan matematika merupakan salah satu materi sekolah yang sangat ditakuti oleh para siswa. Dengan teknologi virtual reality ini mengajak siswa bermain dan belajar sehingga siswa mampu mengerjakan soal matematika dengan cara yang menyenangkan. Acuan yang digunkan dalam penelitian adalah bahwa dengan media virtual reality dapat menjadikan pembelajaran materi fisika dalam memahami konsep getaran dan bunyi akan lebih menyenangkan dan dapat meningkatkan kemampuan berpikir krtis mahasiswa. Perbedaannya jurnal tersebut memanfaatkan media virtual realitypada materi matematik untuk siswa SD, sedangkan pada penelitian ini media virtual reality dimanfaatk untuk materi fisika pada mahasiswa.

Virtual reality merupakan bagian dari komputer multimedia yang akan menjadi media pembelajaran yang menyenangkan dan efektif untuk mengajarkan konsep getaran dan gelombang yang abstrak menjadi konkrit. Hal ini sejalan dengan penelitian Wibowo Agus dan Gunawan (2015) yang menyatakan bahwa pembelajaran dengan media virtual reality sukses mengakomodasi gaya belajar siswa yang beragam karena mengintegrasikan berbagai dimensi dalam proses pembelajaran. Di era teknologi dan informasi yang semakin maju ini, budaya dengan kearifan lokal tidak boleh dilupakan. Peran kearifan lokal secara kritis mengubah dan membentuk budaya global menjadi bermakna dan sesuai dengan kehidupan sosial dan budaya masyarakat, termasuklah di dalamnya dunia pendidikan.

Kearifan lokal adalah identitas atau kepribadian budaya sebuah bangsa yang menyebabkan bangsa tersebut mampu menyerap, bahkan mengolah kebudayaan yang berasal dari luar/bangsa (Wibowo Agus \& Gunawan, 2015). Identitas dan kepribadian tersebut harus menyesuaikan dengan lingkungan masyarakat sekitar agar nilai-nilai budaya tidak bergeser atau hilang. Kearifan lokal merupakan sarana dalam mengolah kebudayaan dan mempertahankan budaya sendiri dari masuknya budaya asing yang tidak baik. Mahasiswa Prodi Pendidikan Fisika IKIP PGRI Pontianak sebagai generasi muda sekarang dirasakan kurang memperhatikan nilai-nilai budaya yang ada di daerahnya karena cenderung lebih aktif menikmati budaya asing yang masuk dalam bentuk kemajuan teknologi dan informasi, padahal seharusnya mahasiswa harus mengetahui dan mengadopsi nilai-nilai kearifan lokal lebih awal, dan menggunakannya sebagai analisis dalam membedah dan memisahkan budaya asing, sehingga dapat terus melestarikan kebudayaan daerah. Salah satu nilai budaya yang ada di Kalimantan Barat yang sudah kurang dilestarikan adalah alat musik khas suku dayak yaitu sampe.

Sampe adalah salah satu alat musik tradisional suku Dayak di Kalimantan. Sampe dalam bahasa Dayak di artikan "memetik dengan jari". Sama seperti namanya, alat musik ini di mainkan dengan cara di petik. Bentuk dari Sampe ini sama seperti gitar, namun memiliki gagang yang pendek. Selain itu, senar yang di gunakan biasanya hanya menggunakan $3-4$ senar.Sampe yang merupakan alat musik petik khas Kalimantan Barat dapat dimanfaatkan untuk membangun konsep fisika pada materi getaran dan gelombang melalui media pembelajaran virtual reality yang sesuai dengan amanah revolusi industri 4.0. Melalui media virtual reality diharapkan melatih kemampuan berpikir kritis.

Berpikir kritis adalah proses intelektal yang aktif dan penuh dengan ketrampilan dalam membuat pengertian atau konsep, mengaplikasikan, menganalisis, membuat sintesis, dan mengevaluasi. Berpikir kritis merupakan upaya pendalaman kesadaran serta kecerdasan 
membandingkan dari beberapa masalah yang sedang dan akan terjadi sehingga menghasilkan sebuah kesimpulan dan gagasan yang dapat memecahkan masalah tersebut, setiap orang memiliki pola pikir yang berbeda (Achmad Arief, 2007). Akan tetapi, apabila setiap orang mampu berpikir secara kritis, masalah yang mereka hadapi tentu akan semakin sederhana dan mudah dicari solusinya. Oleh karena itu, manusia diberikan akal dan pikiran untuk senantiasa berpikir sehingga menjadikannya hidupnya lebih baik, dan mampu menjalani suatu masalah apapun yang diberikan kepadanya.Seorang yang berpikir kritis mempunyai sikap terbuka dan mudah untuk menerima adanya perbedaan, sangat teliti dalam segala hal, dan mempunyai standar baku dalam menilai sesuatu. Argumen yang disampaikan selalu didasari oleh datadata yang akurat, mampu membuat kesimpulan dengan tepat dari beberapa pernyataan yang ada dan selalu memandang sesuatu dari berbagai sudut pandang yang berbeda.

Peningkatan kemampuan berpikir kritis mahasiswa dapat menimbulkan proses intelektual yang aktif dengan ketrampilan dalam membuat konsep, mengaplikasikan, menganalisis, membuat sintesis, dan mengevaluasiterhadap pemahaman konsep getaran dan gelombang. Dengan melatih kemampuan berpikir kritis, mahasiswa juga akan mampu menyelesaikan masalah yang dihadapi dengan sederhana dan mudah mencari solusinya. Mahasiswa yang memiliki kemampuan berpikir kritis akan mempunyai sikap terbuka dan mudah untuk menerima adanya perbedaan, sangat teliti, argumen yang disampaikan selalu didasari oleh data-data yang akurat, mampu membuat kesimpulan dengan tepat dari beberapa pernyataan yang ada dan selalu memandang sesuatu dari berbagai sudut pandang yang berbeda.

Berdasarkan uraian yang dikemukakan di atas, maka penelitian ini bertujuan untuk meningkatkan kemampuan berpikir kritis dan menanamkan nilai kearifan lokal mahasiswa dengan memanfaatkan media virtual reality berbasis alat musik sampe.

\section{METODE}

Metode yang digunakan dalam penelitian ini adalah metode eksperimen dengan bentuk penelitian Pre-experimental designdan rancangan penelitian One-Group PretestPosttest Design. Penelitian ini dilaksanakan di IKIP PGRI Pontianak. Populasi penelitian ini adalah seluruh mahasiswa Semester II Prodi Pendidikan Pontianak tahun ajaran 2019/2020. Teknik pengambilan sampel yang digunakan adalah teknikprobability sampling. Pengambilan sampel yang nantinya semua mahasiswa dalam 1 kelas tersebut yang akan dijadikan sampel penelitian. Sampel dalam penelitian ini terdiri dari mahasiswa Semester II yang berjumlah 11mahasiswa. Variabel bebas dalam penelitian ini adalah media virtual reality yang diajarkan dengan menggunakan metode inkuiri. Variabel terikat dalam penelitian ini adalah kemampuan berpikir kritis mahasiswa.

Teknik yang digunakan dalam penelitian ini adalah teknik pengukuran yang diberikan sebelum (pretest) dan setelah perlakuan (posttest). Instrumen yang digunakan untuk mengukur kemampuan berpikir kritis mahasiswa adalah tes soal kemampuan berpikir kritis berbentuk pilihan ganda yang terdiri dari 10 soal yang memuat beberapa indikator kemampuan berpikir kritis mahasiswa yaitu meliputi: memberi penjelasan sederhana, membangun keterampilan dasar, menyimpulkan, memberikan penjelasan lanjut dan mengatur strategi dan taktik. Instrumen tes yang digunakan terlebih dahulu di validasi empiris kemudian dilakukan uji coba soal, setelah itu dilakukan uji validitas, reliabilitas, menghitung daya pembeda dan tingkat kesukaran soal. Sebelum dilakukan pengujian hipotesis terlebih dahulu dilakukan uji normalitas dan homogenitas data. Data kemampuan berpikir kritis dianalisis dengan menggunakan statistik deskriptif yaitu uji effect size. 


\section{HASIL DAN PEMBAHASAN}

Hasil pretest dan posttestkemampuan berpikir kritis mahasiswa diolah dengan menggunakan statistik deskriptif. Adapun hasil rangkuman rata-rata pretest dan posttestkemampuan berpikir kritis mahasiswa dapat dilihat pada Gambar 1.

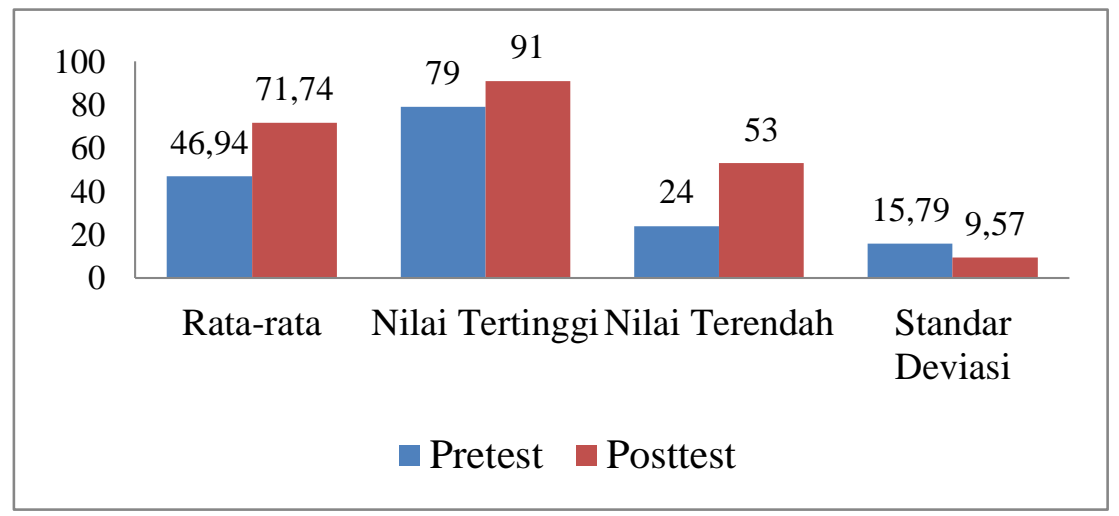

Gambar 1 Data Hasil Pretest dan Posttest Kemampuan Berpikir Kritis mahasiswa

Berdasarkan Gambar 1 dapat diketahui bahwa nilai terendah mahasiswa pada hasil pretest adalah 24 , sedangkan nilai tertinggi adalah 79 . Hasil pretest menunjukkan bahwa kemampuan berpikir kritis dari 11 mahasiswa masih dikatakan rendah dengan rata-rata nilai 46,94 dan standar deviasi 15,79. Sedangkan untuk hasil posttest pada nilai terendah 53 sedangkan nilai tertinggi adalah 91. Hasil posttest menunjukkan bahwa hasil kemampuan berpikir kritis mahasiswalebih tinggi dibandingkan dengan pretest dengan rata-rata 71,74 dan standar deviasi 9,57.

Hasil rekapitulasi kemampuan berpikir kritis mahasiswa berdasarkan rata-rata keterampilan proses sains per indikator pada pretest dan posttest dapat dilihat pada Tabel 2.

Tabel 1. Rata-rata Keterampilan Kemampuan Berpikir Kritis Mahasiswa Pada Pretest dan Posttest

\begin{tabular}{cccccc}
\hline \multirow{2}{*}{ No } & \multirow{2}{*}{ Aspek } & \multicolumn{4}{c}{ Indikator Tiap Aspek } \\
\cline { 3 - 6 } & & \multicolumn{2}{c}{ Pretest } & \multicolumn{2}{c}{ Posttest } \\
\cline { 3 - 6 } & & Nilai & Kriteria & Nilai & Kriteria \\
\hline 1 & Memfokuskan pertanyaan & 86 & SB & 92 & SB \\
2 & Mengobservasi & 54 & KB & 78 & B \\
3 & Menyimpulkan & 54 & KB & 78 & B \\
4 & Mengidentifikasikan asumsi & 21 & SKB & 45 & KB \\
5 & Menentukan tindakan & 77 & B & 97 & SB \\
\hline \multicolumn{2}{c}{ Rata-rata } & \multicolumn{2}{c}{ Kurang Baik } & \multicolumn{3}{c}{ Baik } \\
\hline
\end{tabular}

Berdasarkan Tabel 1 dapat diketahui bahwa nilai minimum mahasiswa pada pretest adalah 21 dengan kriteria (SKB) Sangat Kurang Baik pada aspek mengidentifikasi asumsi, aspek mengobservasi dan menyimpulkan adalah 54 dengan kriteria (KB) Kurang Baik, aspek menentukan tindakan adalah 77 dengan kriteria (B) Baik, sedangkan nilai maksimum terdapat pada aspek memfokuskan pertanyaan dengan nilai 86 dengan kriteria (SB) Sangat Baik. 
Selanjutnya untuk nilai minimum mahasiswa pada posttest adalah 45 dengan kriteria (KB) Kurang Baik pada aspek mengidentifikasi asumsi, aspek mengobservasi dan menyimpulkan adalah 78 dengan kriteria (B) Baik, aspek memfokuskan pertanyaan adalah 92 dengan kriteria (SB) sangat baik, sedangkan nilai maksimum terdapat pada aspek menentukan tindakan dengan nilai 97 dengan kriteria (SB) Sangat Baik. Kemampuan berpikir kritis mahasiswa pada pretest menunjukkan bahwa kemampuan berpikir kritis mahasiswarendah dengan ratarata 46,94 dengan kriteria (KB) Kurang Baik. Sedangkan kemampuan berpikir kritis mahasiswapada posttest menunjukkan rata-rata sebesar 71,74 dengan peningkatan kriteria menjadi (B) Baik.

Uji normalitas data menggunakan statistik Liliefors terhadap hasil pretest dan posttest kemampuan berpikir kritis mahasiswa. Kriteria pengujian Liliefors data adalah jika $L_{\text {hitung }}<$ $L_{\text {tabel }}$ maka data berdistribusi normal, dan jika $L_{\text {hitung }}>L_{\text {tabel }}$ maka data tidak berdistribusi normal.

Tabel 2. Hasil Uji Normalitas Data Pretest dan Posttest

\begin{tabular}{ccc}
\hline Statistik & Data Pretest & Data Posttest \\
\hline $\mathrm{L}_{\text {hitung }}$ & 0,090 & 0,103 \\
$\mathrm{~L}_{\text {tabel }}$ & 0,150 & 0,150 \\
Kesimpulan & Data Berdistribusi & Data Berdistribusi \\
& Normal & Normal \\
\hline
\end{tabular}

Berdasarkan Tabel 2 diperoleh bahwa pada data hasil pretest $L_{\text {hitung }}$ memiliki nilai sebesar 0,090 dan pada data hasil posttest $L_{\text {hitung }}$ memiliki nilai sebesar 0,103 terlihat bahwa $L_{\text {hitung }}$ lebih kecil dari nilai $L_{\text {tabel }}$. Dapat disimpulkan bahwa data pretest dan posttest berdistribusi normal.

Uji homogenitas dilakukan untuk mengetahui kehomogenan varian antara kedua keadaan yaitu pretest dan posttest. Pada penelitian ini digunakan uji homogenitas yaitu Uji Fisher (F) pada taraf signifikan $(\alpha=0,05)$. Dari hasil pengujian diperoleh varians dari data pretest 249,324. Sedangkan varians dari data posttest 91,585. Adapun derajat kebebasan (dk) untuk menentukan $\mathrm{F}_{\text {tabel }}$ yaitu $\mathrm{dk}_{1}=34$ dan $\mathrm{dk}_{2}=34$. Berdasarkan perhitungan diketahui bahwa $F_{\text {hitung }}>F_{\text {tabel }}(2,72>1,81)$. Artinya varians pada data pretest dan posttest tidak homogen.

Karena kedua data berdistribusi normal tetapi tidak homogen, maka digunakan uji t untuk membuktikan hipotesis tersebut. Adapun uji statistik yang digunakan adalah uj-t separated varian dengan $(\alpha=0,05)$. Berdasarkan perhitungan nilai $t_{\text {hitung }}$ lebih besar dari pada nilai $t_{\text {tabel }}$ dimana nilai $t_{\text {hitung }}=7,94$ dan $t_{\text {tabel }}=2,03(7,94>2,03)$. Dengan demikian $\mathrm{H}_{\mathrm{o}}$ ditolak dan $\mathrm{H}_{\mathrm{a}}$ diterima. Artinya, terdapat perbedaan sebelum dan sesudah diterapkan media Virtual Reality untuk meningkatkan kemampuan berpikir kritis mahasiswa.

Untuk mengetahui besar pengaruh mediamedia Virtual Realityterhadap kemampuan berpikir kritis mahasiswa pada materi getaran dan gelombang digunakan rumus effect size. Dari hasil perhitungan effect size diperoleh effect size sebesar 1,57 dengan kriteria tergolong tinggi.

Berpikir kritis dalam penelitian ini adalah proses intelektual yang aktif dan penuh dengan ketrampilan dalam membuat pengertian atau konsep, mengaplikasikan, menganalisis, membuat sintesis, dan mengevaluasi. Menurut Scriven (2001), berpikir kritis merupakan upaya pendalaman kesadaran serta kecerdasan membandingkan dari beberapa masalah yang sedang dan akan terjadi sehingga menghasilkan sebuah kesimpulan dan gagasan yang dapat 
memecahkan masalah tersebut. Ciri-ciri mahasiswa yang berpikir kritis, antara lain: mempunyai sikap terbuka, mudah untuk menerima adanya perbedaan, sangat teliti dalam segala hal, mempunyai standar baku dalam menilai sesuatu, argumen yang disampaikan selalu didasari oleh data-data yang akurat, mampu membuat kesimpulan dengan tepat dari beberapa pernyataan yang ada dan selalu memandang sesuatu dari berbagai sudut pandang yang berbeda.

Mahasiswa yang memiliki kemampuan berpikir kritis akan lebih semangat dalam belajar, mereka selalu ingin mencari tahu jawaban dari permasalahan yang mereka temui saat belajar, selalu termotivasi untuk membuktikan sesuatu/konsep yang mereka peroleh/pelajari. Hal ini dapat dilihat pada saat melakukan percobaan, mahasiswa yang memiliki kemampuan berpikir kritis tinggi akan lebih serius dalam melakukan penyelidikan, memiliki rasa ingin tahu yang besar, bertanggung jawab dalam kelompoknya, teliti dan jujur dalam pengambilan data, dan menghargai pendapat teman-temannya (Wade dalam Achmad, 2007). Sedangkan mahasiswa yang memiliki kemampuan berpikir rendah, cenderung tidak percaya diri dalam belajar dan pasif dalam melakukan percobaan/penyelidikan. Mereka tidak memiliki sikap terbuka terhadap sumber-sumber terbaru, sulit untuk menerima adanya perbedaan, tidak teliti, argumen yang disampaikan tidak didasari oleh data-data yang akurat, dan tidak mampu membuat kesimpulan dengan tepat dari beberapa pernyataan yang ada selama proses pembelajaran. Sehingga hasil hasil belajar yang mereka peroleh juga rendah.

Mahasiswa yang mempunyai kemampuan berpikir kritis mudah dalam menemukan dan menyelesaikan permasalahan yang diberikan. Selain itu dengan melatih kemampuan berpikir kritis, mahasiswa akan lebih mendukung untuk bereaksi atau merespon suatu tindakan yang baru. Dari kondisi itu diketahui bahwa kemampuan berpikir kritis berpengaruh terhadap hasil belajar.

Media pembelajaran dengan menggunakan Virtual reality memberikan simulasi suatu lingkungan oleh komputer dengan menciptakan pengalaman nyata bagi mahasiswa kedalam dunia virtual dalam memahami konsep getaran dan gelombang secara langsung melalui alat musik sampe. Media virtual reality dirancang untuk menghasilkan tujuan dalam menyelesaikan permasalahan yang ditemukan dalam proses pembelajaran getaran dan gelombang. Lingkungan digital imersif yang dibuat dalam sebuah interaksi buatan, adegan atau lingkungan yang diciptakan komputer dimana mahasiswa sebagai pengguna dapat membenamkan diri kedalam dunia ciptaan tersebut dalam memahami konsep yang abstrak menjadi konkrit.

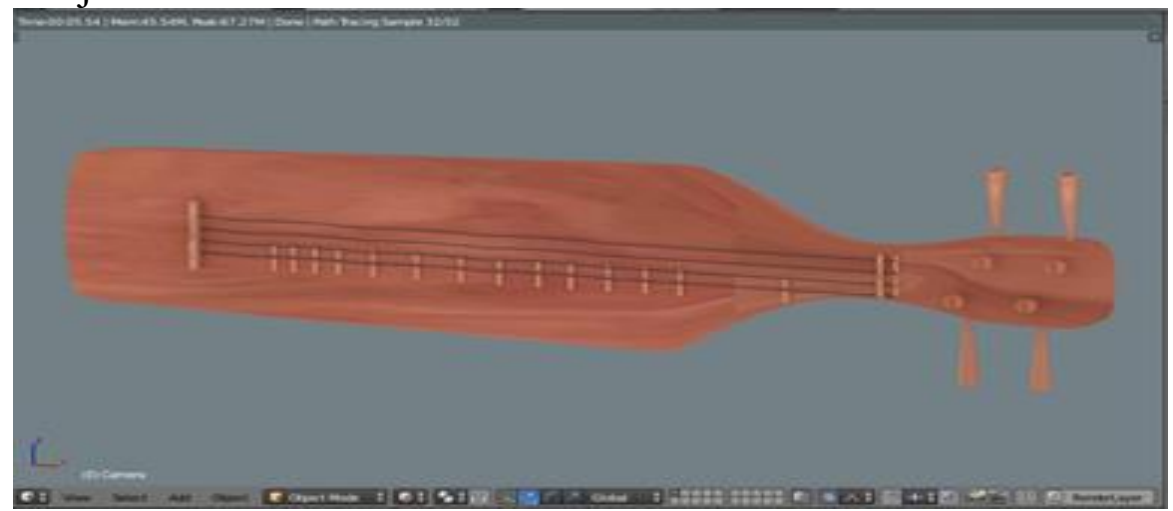

Gambar 2. Media VR Berbasis Kearifan Lokal Alat Musik Sampe

Mahasiswa merasakan sensasi langsung secara visualisasi dalam praktik penggunaan media virtual reality menggunakan alat VR 3D. Mahasiswa menjadi sangat antusias mengikuti proses pembelajaran karena baru pertama kalinya menggunakan alat VR 3D dalam kehidupannya. Pengalaman proses pembelajaran dirasakan mahasiswa sangat menyenangkan dan bisa membantu mahasiswa dalam memahami konsep materi getaran dan gelombang dari 
abstrak menjadi konkrit melalui tampilan visualisasi berupa alat musik sampe khas Kalimantan Barat yang. Hal ini dapat dilihat dari hasil penilaian posttest yang mengalami peningkatan dari hasil penilaian pretest mahasiswa.

Pemanfaatan media Virtual Reality berbasis kearifan lokal melalui alat musik Sampe untuk meningkatkan kemampuan berpikir kritis mahasiswa dalam mengaitkan antara pemanfaatan teknologi dengan meningkatkan nilai kearifan lokal kebudayaan asli Kalimantan Barat. Keunggulan dari pemanfaatan media ini adalah mahasiswa diberikan kesempatan secara langsung untuk memperoleh pemahaman konsep getaran dan gelombang terutama pada gelombang bunyi yang di tampilkan secara konkrit melalui tampilan alat musik sampeyang menyenangkan dan efektif. Media Virtual Reality menghasilkan suasana realistis tiga dimensi pada materi getaran dan gelombang pada alat musik Sampe sehingga mahasiswa dapat merasakan langsung melalui penglihatan, pendengaran, dan sentuhan.

Media virtual reality secara nyata mensimulasikan konsep yang terdapat dalam materi getaran dan gelombang seperti berada di lingkungan alami termasuk dengan penglihatan, pendengaran dan gerakan secara jelas mengamati lingkungan virtual berupa konsep dalam meningkatkan kemampuan berpikir kritis mahasiswa dan merasa seperti berada ditempat tersebut, yaitu penggunaan alat musik sampe yang mengenalkan kepada mahasiswa tentang alat musik sampe untuk meningkatkan nilai kearifan lokal budaya khas Kalimantan Barat. Kebanyakan mahasiswa yang asli Kalimantan Barat yang tersebar dari berbagai daerah dan suku menyatakan bahwa mereka tidak mengetahui tentang alat musik khas Kalimantan Barat yaitu sampe, bahkan mahasiswa yang asli suku dayak juga tidak pernah melihat secara langsung alat musik sampe tersebut. Setelah mahasiswa melakukan proses pembelajaran dengan menggunakan media virtual reality melalui alat VR 3D, mahasiswa dapat melatih kemampuan berpikir kritis dalam aspek memfokuskan pertanyaan, mengobservasi, mengidentifikasi asumsi, menyimpulkan, dan menentukan tindakan. Hal ini sesuai dengan tujuan penelitian ini untuk meningkatkan kemampuan berpikir kritis mahasiswa dan nilai kearifan lokal mahasiswa terhadap alat musik sampe, yang diharapkan kedepannya mahasiswa bisa lebih memahami dan menjaga nilai kearifan lokal di daerahnya.

\section{KESIMPULAN}

Berdasarkan hasil penelitian dan analisis data secara umum dapat disimpulkan bahwa pemanfaatan media Virtual Reality berbasis kearifan lokal melalui alat musik sampe berpengaruh terhadap kemampuan berpikir kritis mahasiswa pada materi getaran dan gelombang pada Mahasiswa Prodi Pendidikan Fisika IKIP PGRI Pontianak. Adapun kesimpulan secara khusus dari penelitian ini adalah sebagai berikut: (1) Kemampuan berpikir kritis mahasiswa sebelum diajarkan dengan media virtual reality untuk aspek memfokuskan pertanyaan diperoleh kriteria (Sangat Baik), mengobservasi (Kurang Baik), menyimpulkan (Kurang Baik), mengidentifikasi (Sangat Kurang Baik), menentukan tindakan (Baik), dengan rata-rata pretest 47 dengan kriteria (Kurang Baik). Sesudah diterapkan media virtualrealitymengalami peningkatan dengan hasil tes untuk aspek memfokuskan pertanyaan diperoleh kriteria (Sangat Baik), mengobservasi (Baik), menyimpulkan (Baik), mengidentifikasi asumsi (Kurang Baik), menentukan tindakan (Sangat Baik), dengan ratarata posttest keseluruhan sebesar 72 dengan peningkatan kriteria menjadi (Baik), (2) Terdapat perbedaan sebelum dan sesudah diterapkan media virtual reality terhadap Kemampuan berpikir kritis mahasiswa pada materi getaran dan gelombang pada Mahasiswa Prodi Pendidikan Fisika Semester II IKIP PGRI Pontianak, (3) Besar pengaruh media virtual reality terhadap Kemampuan berpikir kritis mahasiswa pada materi getaran dan gelombang pada Mahasiswa Prodi Pendidikan Fisika Semester II IKIP PGRI Pontianak sebesar 1,57 dengan kategori tergolong tinggi. 


\section{SARAN}

Berdasarkan kesimpulan dalam penelitian ini, maka peneliti mengajukan saran-saran sebagai berikut: (1) Media Virtual Reality bisa di desain dalam bentuk 4D agar tampilan animasi dalam VR-Box lebih nyata lagi, (2) Referensi untuk bahan kearifan lokal masih sangat kurang, sehingga bahan kajian tentang alat musik sampe sangat kurang.

\section{UCAPAN TERIMA KASIH}

Peneliti mengucapkan terima kasih kepada RISTEKDIKTI yang telah mendanai penelitian dosen pemula ini.

\section{DAFTAR PUSTAKA}

Arief, Achmad. 2007.Memahami Berpikir Kritis. (Online), (http://re-searchengines.com /1007arief3.html), diakses 24 Mei 2011.

Chau-kiu, C dan Lee, T. (2010). Improving Social Competence Through Character Education. Evaluation and Program Planning.255-263.

Liu, Q. (2012). The Virtual Reality Technology in Art Design. $2^{\text {nd }}$ Internasional Conference on Consumer Electronics, Communications and Networks, pp 22226-2228.

Negeriku Indonesia. (2015). Sampe Alat Musik Tradisional Suku Dayak di Kalimantan. Rerieved from http://www.negerikuindonesia.com/2015/04/ sampe-alat-musiktradisional-suku-dayak.html

Scriven, Michael. 2001. An National Council for Excellence. Critical Thinking Instruction.

Sulistyowati, Andy Rachman. (2017). Jurnal Ilmiah NERO. Volume 3. Nomor 1. 37-44.

Sunarni, Theresia, Dominikus dan Budiarto. (2014). Persepsi Efektivitas Pengajaran Bermedia Virtual Reality (VR). Seminar Nasional Teknologi Informasi dan Komunikasi Terapan. ISSN: 979-26-0276-3. 179-184.

Sutrisno, Joko. (2010). Menggunakan Ketrampilan Berpikir untuk Meningkatkan Mutu Pembelajaran. (Online), (http://www.scribd.com/doc/54977805/artikel-erlangga) diakses 18 Mei 2018.

Wibowo, Agus \& Gunawan. (2015). Pendidikan Karakter Berbasis Kearifan Lokal di Sekolah. Yogyakarta: Penerbit Erlangga.

Zhang, L \& Zheng, G. (2011). The Virtual Campus Scene Based on VRML. 2011 International Conference on Multimedia Technology, pp 912-915 